\title{
PENGEMBANGAN KARAKTER SPIRITUAL KEAGAMAAN SISWA DALAM PERSPEKTIF ISLAM
}

\author{
Asep Muljawan \& Saiful Ibad \\ Dosen STAI Asy-Syukriyyah Tangerang \& \\ Universitas Muhammadiyah Jakarta \\ asep.muljawan@asy-syukriyyah.ac.id \\ saifulibadkusaeri@gmail.com
}

\begin{abstract}
Abstrak
Pendidikan merupakan ujung tombak dalam mempersiapkan generasi harapan masa depan. Salah satu ciri generasi tersebut adalah memiliki karakter spiritual keagamaan. Tulisan ini mengkaji pengembangan karakter spiritual keagamaan berdasarkan alqur'an, hadits dan pandangan para ulama dengan metode atau pendekatan tematik-normatif. Karakter yang dimaksud antara lain: (1) belajar harus dilandasi niat karena Allah (Ikhlas), (2) menerapkan karakter profetik (sidq, amanah, tabligh, dan fathonah), (3) fokus belajar dan haus ilmu pengetahuan, (4) makan makanan halal secukupnya, tidak maksiat dan banyak zikir, (5) sedikit tidur dan bicara, (6) menjaga rasa hormat terhadap guru. Keenam karakter spiritual keagamaan ini menjadi prioritas utama dalam Pendidikan Islam. Sementara Pendidikan Barat lebih memperhatikan pada metode dan strategi pembelajaran, profesionalitas guru, ketepatan sumber belajar, dan yang paling menonjol adalah tuntutan kepemimpinan dalam mengelola lembaga Pendidikan.
\end{abstract}

Kata Kunci: Karakter, Spiritual Keagamaan, Islam.

\section{Abstract}

Education is the spearhead in preparing future generations of hope. One of the characteristics of these generations is having a religious spiritual character. This paper examines the development of religious spiritual character based on the qur'an, hadits and the views of the ulama with thematic-normative approaches. The intended characters include: (1) learning must be on intention because of Alloh, (2) applying prophetic character (sidq, amanah, tabligh, fathonah), (3) focus on learning and thirst for knowledge, (4) eating halal food in moderation, not immoral and many remembrance, (5) little sleep and talk, (6) maintaining respect for teachers. These six spiritual characteristics are the main priorities in Islamic education. While western education places more emphasis on learning methods and strategies, teacher professionalism, accuracy of learning resources and the demands of leadership in managing educational institutions.

Keywords: character, religious spiritual, Islamic. 


\section{Jurnal Asy-Syukriyyah}

\section{A. PENDAHULUAN}

Pendidikan merupakan masalah penting bagi kehidupan manusia, membantu manusia menuju ke arah pertumbuhan dan perkembangan. UU No. 20 Tahun 2003 Tentang Sistem Pendidikan Nasional dalam ketentuan umum menyatakan bahwa pendidikan adalah usaha sadar dan terencana untuk mewujudkan suasana belajar dan proses pembelajaran agar peserta didik secara aktif mengembangkan potensi dirinya untuk memiliki kekuatan spiritual keagamaan, pengendalian diri, kepribadian, kecerdasan, akhlak mulia, serta keterampilan yang diperlukan dirinya, masyarakat, bangsa dan negara. Selanjunya pasal ini menyatakan bahwa Pendidikan nasional adalah pendidikan yang berdasarkan Pancasila dan Undang-Undang Dasar Negara Republik Indonesia Tahun 1945 yang berakar pada nilainilai agama, kebudayaan nasional Indonesia dan tanggap terhadap tuntutan perubahan zaman. Selanjutnya pasal ini juga menyatakan bahwa sistem pendidikan nasional adalah keseluruhan komponen pendidikan yang saling terkait secara terpadu untuk mencapai tujuan pendidikan nasional ${ }^{1}$. Pendidikan nasional berdasarkan Pancasila dan UndangUndang Dasar Negara Republik Indonesia Tahun $1945^{2}$. Pendidikan nasional berfungsi mengembangkan kemampuan dan membentuk watak serta peradaban bangsa yang bermartabat dalam rangka mencerdaskan kehidupan bangsa, bertujuan untuk berkembangnya potensi peserta didik agar menjadi manusia yang beriman dan bertakwa kepada Tuhan Yang Maha Esa, berakhlak mulia, sehat, berilmu, cakap, kreatif, mandiri, dan menjadi warga negara yang demokratis serta bertanggung jawab ${ }^{3}$.

Undang-Undang Sistem Pendidikan Nasional tersebut memberikan pemahaman bahwa sisi-sisi spiritualitas keagamaan siswa harus mendapatkan perhatian karena ia merupakan bagian tujuan pendidikan nasional. Pendidikan nasionanl yang mendasarkan

1 Undang-Undang Republik Indonesia Nomor 20 Tahun 2003 Tentang Sistem Pendidikan Nasional, pasal 1.

2 Undang-Undang Republik Indonesia Nomor 20 Tahun 2003 Tentang Sistem Pendidikan Nasional, pasal 2.

${ }^{3}$ Undang-Undang Republik Indonesia Nomor 20 Tahun 2003 Tentang Sistem Pendidikan Nasional, pasal 3. 


\section{Jurnal Asy-Syukriyyah}

pada Pancasila dan Undang-Undang Dasar 1945 memberi arti bahwa spririt dan nilai-nilai keagamaan yang melandasi keduanya juga melandasi sistem pendidikan nasional. Disamping bertujuan untuk berkembangnya potensi peserta didik agar menjadi manusia sehat, berilmu, cakap, kreatif, mandiri, dan menjadi warga negara yang demokratis serta bertanggung jawab, pendidikan nasional mengutamakan tujuan berkembangnya potensi peserta didik agar menjadi manusia yang beriman dan bertakwa kepada Tuhan Yang Maha Esa dan berakhlak mulia. Hal ini sejalan dengan penempatan nilai-nilai ketuhanan pada sila pertama dalam Pancasila, dan penyebutan "berkat rakhmat Allah Yang Maha Kuasa" serta penyebutan "bentuk Negara Republik Indonesia yang berkedaulatan rakyat dengan berdasarkan kepada Ketuhanan Yang Maha Esa" dalam Preambule UUD 1945. Spirit dan nilai-nilai ketuhanan harus hadir dalam pendidikan nasional dari visi, misi, dasar, fungsi, tujuan, prinsip penyelenggaran, kurikulum, sarana dan prasarana, pendanaan, pengelolaan (manajemen), evaluasi, akreditasi, sertifikasi dan pengawasan di setiap jalur dan jenjangnya.

Karakter spiritual keagamaan semestinya bukan hanya menjadi target pencapaian di akhir kelulusan peserta didik, melainkan harus tertanam sejak peserta didik duduk di bangku sekolah. Hubungan murid dan guru harus dilandasi karakter spiritual keagamaan baik di kelas maupun di luar kelas. Terdapat banyak fakta guru hanya dianggap sebagai guru yang dihormati hanya di kelas, tidak di luar kelas. Di luar kelas guru dipandang sosok orang biasa yang tidak harus dihormati karena tidak dalam kontrak belajar. Bahkan ada banyak kasus larangan guru di luar sekolah diabaikan. Tindakan guru dalam konteks pendidikan pun sering disalahartikan oleh siswa dan dilaporkan pada orang tua siswa, dan kemudian masuk ranah hukum dengan pelaporan orang tua siswa pada pihak yang berwajib bahwa anaknya di sekolah dilaporkan mengalami penganiayaan oleh seorang guru. Padahal perlakuan guru itu merupakan ijtihad guru sebagai treatmen terhadap para 
siswa yang berlaku tak beradab dalam pembelajaran di kelas ${ }^{4}$. Ahmad Budi Cahyono, guru honorer di SMAN 1 Torjun, Kabupaten Sampang, Madura, Jawa Timur, meninggal dunia pasca-mengalami tindak kekerasan yang diduga dilakukan oleh siswanya sendiri. Dihimpun dari berbagai sumber menyebutkan, dugaan kekerasan tersebut dilakukan oleh siswanya berinisial MH, asal Dusun Brekas, Torjun Timur, Desa/Kecamatan Torjun Sampang. MH disebutkan siswa yang masih duduk di kelas XI ${ }^{5}$. Masih banyak kasuskasus lain yang mencerminkan immoralitas siswa didik terhadap gurunya. Pertanyaan yang dapat diajukan "apakah sikap-sikap negatif siswa didik ini menjadi salah satu indikator ketidakberhasilan pengembangan spiritual keagamaan dalam proses pembelajaran di kelas?

Tulisan ini bertujuan mendiskripsikan konsep-konsep Islam tentang karakterkarakter spiritual keagamaan apa saja yang seharusnya dimiliki dan dipraktekkan siswa di kelas agar terjadi hubungan baik antara siswa dengan siswa didik lainnya, dan antara siswa didik sebagai perseorangan dan sebagai kelompok dengan gurunya. Norma-norma keislaman yang bersumber dari al-Qur`an dan al-Hadits dan pandagan para ulama akan dikemukakan untuk memberikan solusi (syifa') terhadap problem krisis moral siswa yang marak terjadi belakangan ini.

Problem krisis moral siswa ini akan dianalisis dengan menggunakan metode atau pendekatan tematik-normatif (thematic-normatif approach). Norma-norma keislaman yang bersumber pada al-Qur`an dan al-Hadits, dan pandangan para ulama ('aqwaal al-'ulamaa) akan dijadikan alat untuk mengukur benar-tidak, baik-buruk, dan patut-tidak patutnya sebuah problem secara tematik. Agama Islam sebagai agama yang rahmatan lil alamin tentunya mempunyai konsep atau ajaran yang bersifat manusiawi dan universal yang dapat memberikan alternatif pemecahan terhadap problem ummat manusia yang hidup di dunia modern dan era global ini $^{6}$. Pandangan Islam sebagai agama yang sempurna dan Islam

\footnotetext{
${ }^{4}$ Okenews (2019) "Viral Murid Tantang Guru karena HP-nya Disita, Teman Sekelas Malah Tepuk Tangan" edisi Jumat 22 Februari.

${ }_{5}^{5}$ Pos-Kupang.Com. (2019) "Inilah sosok HH, Siswa SMA yang Pukul Gurunya hingga Tewas dan Kronologi Kejadian” edisi Kamis 25 Juli 2019.

${ }^{6}$ Rosihan Anwar, dkk Pengantar Studi Islam. Bandung : Pustaka Setia, 2004. hlm 31.
} 


\section{Jurnal Asy-Syukriyyah}

dapat dipastikan menjawab semua persoalan kehidupan ini dilandaskan pada pernyataan alQur`an tentang kesempurnaannya ${ }^{7}$, dan pernyataan al-Qur`an bahwa ia diturunkan sebagai “obat"-syifaa ${ }^{-8}$. Pendekatan, metode dan analisis model ini disebut sebagai pendekatan normatif. Meskipun model analisis ini sering mendapat kritikan dalam studi Islam di Barat. Mereka menganggap model studi ini dipertanyakan keilmiahannya karena dipandang bersifat apologis-normatif. Kritik yang mendekati Barat juga dilontarkan Amin Abdullah. Baginya, pendekatan normatif yang berangkat dari teks kitab suci pada akhirnya membuat corak pemahaman yang tekstualis dan skripturalis dan dianggap cenderung bersifat absolutis karena mengabsolutkan teks tertulis tanpa mau memahami lebih dahulu mengapa dan apa yang melatarbelakangi munculnya teks keagamaan tersebut ${ }^{9}$. Sebagai model studi, analisis normatif sudah banyak digunakan oleh para ilmuan dan peneliti terutama di kawasan Timur Tengah, dan di banyak UIN, IAIN dan STAIN di Indonesia. Saya memadukan analisis normatif ini dengan model pendekatan tematik, sehingga model ini menjadi analisis tematik-normatif.

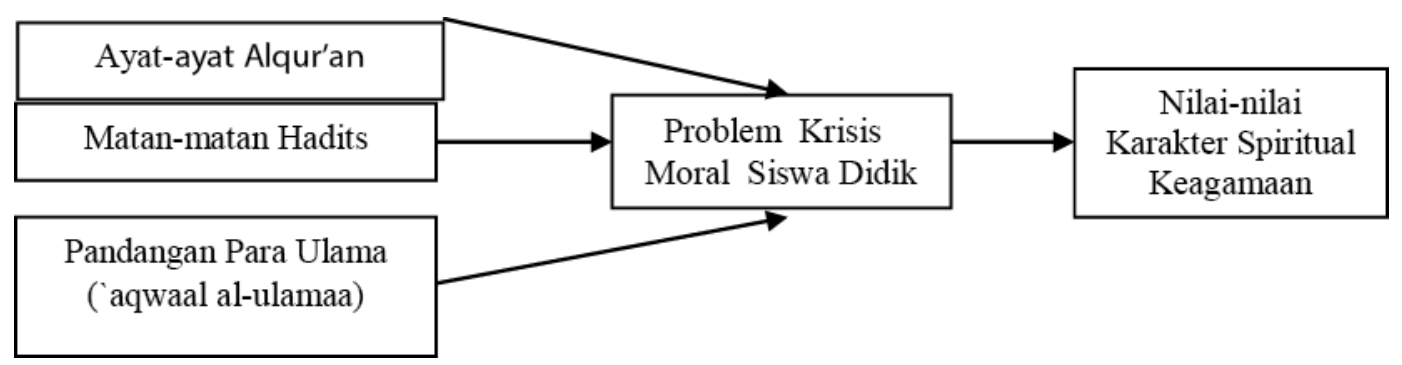

\section{B. PEMBAHASAN}

Ada banyak karakter spitual keagamaan yang dapat dideskripsikan dari ayat ayat alQur`an, Hadis-Hadis Rasulullah SAW, dan dari pandangan para ulama. Minimal dapat diangkat enam karakter. Keenam karakter ini dalam dapat ditelusuri dalam praktik pendidikan dari zaman Rasulullah hingga tradisi ulama salaf saleh sebagai berikut:

\footnotetext{
${ }^{7}$ Alqur'an Surat Al-Maidah Ayat 3:

${ }^{8}$ Alqur'an Surat Al-Isra Ayat 82:

9 M. Amin Abdullah, dkk. Islamic Studies dalam Paradigma Integrasi Interkoneksi (Sebuah
} Antologi). Yogyakarta: SUKA Press. 2007, hlm V. 


\section{Jurnal Asy-Syukriyyah}

\section{Tulus (Ikhlas)}

Ikhlas dalam Islam menjadi ruh setiap tindakan. Setiap perbuatan yang tidak didasari keikhlasan, perbuatan itu menjadi sia-sia laksana fisik tanya nyawa. Prinsip ikhlas ini sesungguhnya menjadi kekuatan yang menggerakan setiap amal muslim. Dengan ikhlas, muslim dapat mempfokuskan diri terhadap apa yang sedang dikerjakannya. Perinsip ikhlas ini harus dikembangakan pada diri siswa didik agar mereka menjadi pribadi yang menerapkan prinsip ini dalam kegiatan pembelajaran. Ikhlas akan membatasi siswa didik dari motifmotif dunia dalam belajar, meskipun sesungguhnya hal ini wajar, tetapi Islam mengajarkan prinsip ikhlas agar dalam menuntut ilmu hanya memiliki satu motivasi yaitu karena dorongan perintah Allah SWT. Kehadiran unsur ilahiah dalam belajar ini dapat disebut sebagai unsur karakter spiritual keagamaan.

Menurut al-Gazali, niat (al-niyah), kehendak (al-`iraadah) dan kesengajaan (alqasd) adalah tiga kata yang mengarah pada makna yang sama, yaitu suasana hati yang mampu melahirkan pengetahuan dan tindakan. Pengetahuan lahir terlebih dahulu baru kemudian lahir tindakan karena tindakan itu buah dari pengetahuan ${ }^{10}$. Dengan demikian para siswa didik harus mendapat pengetahuan tentang ikhlas dalam belajar, dan kemudian dirangsang agar nilai-nilai yang terkandung dalam ikhlas itu masuk ke dalam penjiwaan. Penjiwaan nilai-nilai ikhlas akan melahirkan sikap belajar yang positif berupa motivasi dan karakter spiritual keagamaan yang mampu meletupkan suasana belajar yang baik, dan melejitkan hasil belajar. Dorongan untuk mengembangkan dan menerapkan karakter spiritual keagamaan ikhlas ini minimal dapat dikonstruk normanya dari al-Qur`an surat alBayyinah ayat 5, al-Qur`an surat al-Kahfi ayat 110, dan Hadis Nabi riwayat Bukhari dan Musli dari Amirul mukminin, Umar bin Khattab.

${ }^{10}$ Harun, Abd al-Salam Muhammad Tahdzib `Ihyaa 'Uluum al-Diin. Kairo: Nasyr Daar Sa'd Mishr li al-Thibaa'ah wa al-Nasyr, tth, hlm 253. 


\section{Menerapkam Karakter Profetik}

Jujur (shidq), dapat dipercaya ( amaanah), menyampaikan pesan atau titipan (tabliigh), dan cerdas (fathaanah) adalah empat karakter dasar Rasulullah SAW yang membuat sukses misi dakwahnya. Empat karakter dasar ini merupakan satu kesatuan yang terkait erat, tak terpisahkan. Empat karakter profetik ini harus ditanamkan dan dipraktekkan oleh siswa didik. Karakter jujur harus dipraktekkan dalam proses pembelajaran di kelas misalnya tidak menyontek dalam ujian dan tugas-tugas mandiri. Karakter amanah misalnya dapat diterapkan dalam mengerjakan tugas-tugas kelompok. Karakter tabligh dapat dipraktekkan dalam pendistribusian tugas-tugas kelas tanpa melakukan sabotase dalam persingan. Karakter fathanah dapat dipraktekkan dengan memberikan tugas-tugas yang dapat melejitkan kecerdasan.

Karakter Rasulullah yang lain, selain empat karakter dasar di atas, adalah bahwa Rasulullah SAW bebas dari trend karakter negatif (al-bid`ah). Karakter negatif saat ini sering menggejala di kalangan siswa didik, seperti karakter bully dan karakter berkelompok untuk menindas siswa di luar kelompoknya. Karakter Rasulullah yang lain yang dapat diteladani siswa didik adalah Rasulullah berpakaian rapi dan bersih. Diriwayatkan dari Abdullah Abi Umamah al-Harisi Rasulullah SAW mengatakan bahwa bersih-rapi dalam berpakaian itu sebagian dari iman ${ }^{11}$. Berdasarkan karakter ini berarti tidak dibenarkan mencoret pakaian saat kelulusan dan mengotori pakaian dengan telur saat pesta ulang tahun. Karakter Rasulullah SAW adalah tidak glamor dalam berpakaian. Rasulullah SAW tidak memakai pakaian yang mahal harganya, hanya pakaian biasa dan bahkan berpakaian standar orang-orang zuhud. Siswa didik harus menghindari segala jenis permainan yang tidak bermanfaat dan bersifat hura-hura ${ }^{12}$. Belajar dari karakter ini, permaian atau game yang berbasis internet yang saat ini sedang menguasai permainan anak harus menjadi perhatian orang tua, guru dan segenap dunia pendidikan. Kebiasaan anak-

${ }^{11}$ al-Albany, Muhammad Nashiruddin, Silsilah al-`Ahaadits alShahiihah. TT., al-Maktabah alIslami., tth, hlm 341.

${ }^{12}$ Al-Baghdadi, Abu Bakr Ahmad ibn Ali ibn Tsabit al-Khathib, AlJaami’ li 'Akhlaaq al-Raawi wa `Aadaab al-Saami. Riyad: Dar al-Maarif, 1403 H, cet. 1. hlm 154. 


\section{Jurnal Asy-Syukriyyah}

anak sekolah nongkrong di mall juga harus menjadi perhatian semua karena membawa dampak buruk bagi mental anak.

\section{Fokus Belajar dan Haus Ilmu Pengetahuan}

Masa remaja adalah masa emas buat belajar. Panca indera yang masih kuat, semangat yang masih menggelora, dan ditopang oleh fisik yang prima membuat masa remaja menjadi penentu nasibnya di masa mendatang. Keberhasilan belajar di masa muda menentukan keberhasilan hidup di masa mendatang. Menurut Ibnul Qoyyim al-Jawjiyyah, fokus belajar itu dapat dicapai dengan cara menyingkirkan segala hambatan-hambatannya. Hambatan-hambatan bagi tercapainya fokus belajar itu biasa berupa kelezatan dunia seperti syahwat duniawi. Cara terbaik untuk melepaskan diri dari kelezatan duniawi adalah dengan cara memalingkannya pada Allah sang pencipta kelezatan duniawi itu sendiri ${ }^{13}$. Kelezatan dan syahwat duniawi ini seperti gadget, kendaraan, rumah mewah, dan fasilitas-fasilitas mewah lainnya. Begitu juga pertemanan yang menjauhkan dari suasana belajar.

\section{Makan Makanan Halal Secukupnya, Tidak Maksiat, dan Banyak Zikir}

Makan makanan yang halal adalah perintah Allah SWT pada setiap hambanya. Mencari rizki yang halal, memakan makanan yang halal, dan mendistribusikan rizki hanya untuk belanja yang halal. Bagi orang yang sedang menuntut ilmu tidak direkomendasikan banyak makan karena banyak makan mengakibatkan banyak minum, dan banyak makan dan minum mengakibatkan banyak ke kamar kecil dan banyak tidur, akibatnya sedikit belajar dan kehilangan banyak kesempatan belajar. Tidak ada dalam sejarahnya para wali dan ulama terkemuka yang makan banyak. Mereka justru makan sedikit hanya untuk memenuhi standar minimal bisa beribadah kepada Allah SWT. Imam Syafi'i berkata "saya merasa makan tidak kenyang selama 16 tahun" ${ }^{14}$. Konsep ini mungkin bertentangan

${ }^{13}$ Rusaln, Abi Abdillah Muhammad ibn Said (1993), `Aadab Thaalib al-'Ilm. Beirut: Daar ibn Hazm, cet. 1. Hlm 48.

${ }^{14}$ Al-Kanani, Ibn Jamaah (T.Th.). Tadzkiir al-Saami wa al-Mutakallim fii `Aadab al- 'Aalim wa alMuta'allim. TT: Dar al-Kutub al-Ilmiah. hlm 74. 


\section{Jurnal Asy-Syukriyyah}

dengan konsep belajar Barat yang menjadikan nutrisi cukup bahkan harus lebih untuk menunjang kerja otak.

Dalam konsep pendidikan Islam, segala bentuk maksiat dapat menjadi kendala belajar seperti lemahnya hapalan siswa didik. Ibrahim bin Adham menyatakan bahwa di antara menjaga dosa itu memakan makanan yang subhat dan meninggalkan sesuatu yang tidak berguna itu adalah meninggalkan yang berlebihan ${ }^{15}$. Siswa didik seharusnya mendapatkan asupan makanan dan minuman yang halal, pakaian yang dikenakan juga dibeli dengan uang yang halal, rumah yang ditinggali juga dibangun, disewa atau dibeli dari sumber dana yang halal. Hal dimaksudkan agar ilmu yang disampaikan seorang guru dalam pembelajaran dapat meresap ke dalam dirinya dengan baik. Karena dalam pendidikan Islam ilmu itu adalah cahaya dan cahaya Allah SWT tidak dianugrahkan pada orang yang mendapatkan asupan, pakaian dan tempat tinggal yang halal. Demikian juga dengan segala alat pendukung pembelajaran seperti buku, ballpoin, laptop dan lain-lainnya juga harus dibeli dengan sumber dana yang halal ${ }^{16}$.

Yang tak kalah penting bagi penuntut ilmu adalah zikrullah di setiap keadaan dan kesempatan. Zikir dapat membantu pintu ilmu pengetahuan. Zikir dapat memberi ketenangan pada hati dan pikiran. Karena dengan zikir dapat membantu melahirkan ide dan gagasan dalam belajar. Kelemahan hati itu dua, pertama lupa dan kedua, potensial berdosa. Zikir dapat mengikis keduanya. Hal ini seperti tertuang dalam al-Qur`an surat alKahfi ayat $28^{17}$.

\section{Sedikit Tidur dan Berbicara}

Tidur bagi siswa didik harus cukup tadi tidak berlebihan. Ketentuan sedikit tidur itu terkait dengan ketentuan sehat. Tapi kalau dikurangi waktu tidur menjadi sakit maka tidak boleh mengurangi waktu tidur karena alasan belajar. Konsep Islam tidak boleh melakukan

${ }^{15}$ Ibnul Qayyim, al-Imam, al-Fawaa `id. Maktabah al-Jaamiah, 1396 H, cet. 3. hlm 21.

${ }^{16}$ Rusaln, Abi Abdillah Muhammad ibn Said 'Aadab Thaalib al-'Ilm. Beirut: Daar ibn Hazm, 1993 H, cet. 1. hlm 69.

${ }^{17}$ Ibnul Qayyim Madaarik al-Salikin. Dar al-Sunnah al-Muhammadiyyah, Tth, hlm 37. 


\section{Jurnal Asy-Syukriyyah}

sesuatu yang membahayakan diri sendiri dan orang lain (laa dharara wa laa dhiraar). Kalau mengurangi tidur membahayakan bagi kesehatannya maka meskipun demi belajar, tidak boleh mengurangi waktu tidur. Standar umum untuk kesehatan, waktu tidur itu minimal 8 jam ${ }^{18}$. Syeikh Zarnuji dalam kitab Ta'lim alMuta'allim Thuruq al-Ta'allum, menceritakan bahwa al-Hasan bin Ziyad tidak kelar kamar selama 40 tahun karena alasan belajar. Muhammad bin Hasan alSyaibani sering tidak tidur semalam suntuk demi menulis kitab. Dalam menulis kitab Muhammad bin Hasan al-Syaibani sering menyiapkan segelas air untuk menghilangkan kantuknya. Menurutnya rasa kantuk itu ibarat panas, maka airlah yang bisa memadamkannya ${ }^{19}$.

\section{Menjaga Rasa Hormat Terhadap Guru}

Tradisi menjaga rasa hormat terhadap guru yang mengajar itu telah terjaga dalam tradisi pendidikan Islam. Tradisi para ulama salaf telah menunjukkan bahwa sang guru mendapatkan posisi yang sangat penting dalam penghormatan. Dikisahkan bahwa Zaid bin Tsabit setelah selesai mensalatkan zanajah, lalu telah disiapkan untuknya seekor untuk tunggangannya, maka ketika datang Ibnu Abbas, seseorang yang dipandangnya sebagai ulama sekaligus seorang guru, maka Zaid bin Tsabit mempersilahkan Ibnu Abbas untuk menaiki unta tunggangan yang sudah dipersiapkan untuknya. Demikian para sahabat dan kaum salaf salih memuliakan seorang guru ${ }^{20}$. Dikisahkan juga bahwa seseorang berguru dan belajar kepada Hasan selama tiga tahun, selama itu pula ia hanya menyimak dan tidak pernah bertanya apapun karena hormat sama sang guru al-Hasan, dan karena takut sang guru terganggu perasaanya. ${ }^{21}$

18 Al-Kanani, ibn jamaah. Tadzkiir al-Saami wa al-Mutakallim fii 'Aadab al-'Aalim wa alMuta'allim., Dar al-Kutub al-Ilmiah. hlm 77.

${ }^{19}$ Zarnuji, Burhanul Islam Ta'lim al-Muta'allim Thuruq al-Ta'allum. Mesir: Dar Ihya al-Kutub alArabiyyah, cet. 1. hlm 23 .

${ }^{20}$ Ibnul Qayyim, al-Imam (1396 H). al-Fawaa id. TT: Maktabah al-Jaamiah, cet. 3. hlm 5.

${ }^{21}$ Al-Baghdadi, Abu Bakr Ahmad ibn Ali ibn Tsabit al-Khathib (1403 H). AlJaami' li 'Akhlaaq alRaawi wa `Aadaab al-Saami. Riyad: Dar al-Maarif, cet. 1. hlm 184. 


\section{Jurnal Asy-Syukriyyah}

\section{KESIMPULAN}

Ada enam karakter spiritual keagamaan yang dapat ditelusuri dari ayat-ayat alQur`an, Hadits-Hadits Rasulullah SAW, dan dari pandangan para ulama salaf saleh. Keenam karakter ini telah dijalankan dalam tradisi keilmuan dan pembelajaran yang terjadi antara murid dan guru. Keenam itu adalah pertama, dalam belajar harus dilandasi niat tulus hanya karena Allah, bukan karena faktor-faktor lain seperti gelar akademik, kehormatan, dan lain-lain; kedua, menerapkan karakter profetik (sidq, amaanah, tabliigh, fathaanah); ketiga, fokus belajar dan haus ilmu pengetahuan; keempat, makan makanan halal secukupnya, tidak maksiat, dan banyak zikir; kelima, sedikit tidur dan berbicara; dan keenam, menjaga rasa hormat terhadap guru. Dengan menjaga dan menerapkan enam karakter ini akan sangat membantu peningkatan prestasi dan mutu pendidikan.

Keenam karakter spiritual keagamaan ini tidak menjadi fokus kajian dalam teoriteori pendidikan Barat. Barat lebih memperhatikan pada metode dan strategi pembelajaran, profesionalitas guru, ketepatan sumber belajar, dan yang paling menonjol adalah tuntutan kepemimpinan dalam mengelola lembaga pendidikan. Barat tidak menitikberatkan pada faktor-faktor etik sehingga terjadi keharmonisan dalam proses belajar mengajar. Faktorfaktor ketersinggungan guru belum dipandang dalam teori Barat sebagai penghambat proses pembelajaran di kelas, sementara konsep Islam melihat itu sebagai penghambat, karena Islam menganggap penghormatan terhadap guru sangat penting dalam konsep pembelajaran, sementara Barat hanya berdasar pada komitmen kontrak belajar yang disepakati bersama. 


\section{Jurnal Asy-Syukriyyah}

\section{DAFTAR PUSTAKA}

Al-Albany, Muhammad Nashiruddin (T,Th.). Silsilah al-`Ahaadits alShahiihah. TT., alMaktabah al-Islami.

Al-Baghdadi, Abu Bakr Ahmad ibn Ali ibn Tsabit al-Khathib (1403 H). Al-Jaami’ li `Akhlaaq al-Raawi wa `Aadaab al-Saami. Riyad: Dar al-Maarif, cet. 1.

Al-Kanani, ibn jamaah (T.Th.). Tadzkiir al-Saami wa al-Mutakallim fii `Aadab al-'Aalim wa al-Muta'allim. TT: Dar al-Kutub al-Ilmiah.

Anwar, Rosihon, dkk (2004). Pengantar Studi Islam. Bandung : Pustaka Setia, 2004.

Harun, Abd al-Salam Muhammad (T.Th.). Tahdzib 'Ihyaa' 'Uluum al-Diin. Kairo: Nasyr Daar Sa'd Mishr li al-Thibaa'ah wa al-Nasyr.

Ibnul Qayyim, al-Imam (1396 H). al-Fawaa id. TT: Maktabah al-Jaamiah, cet. 3.

- (T.Th.). Madaarik al-Salikin. TT: Dar al-Sunnah al-Muhammadiyyah.

. (T.Th.). Al-Waabil al-Shayyib. Mesir: al-Maktabah al-Salafiyyah.

M. Amin Abdullah, dkk. (2007). Islamic Studies dalam Paradigma Integrasi-Interkoneksi (Sebuah Antologi). Yogyakarta: SUKA Press.

Okenews (2019) “Viral Murid Tantang Guru karena HP-nya Disita, Teman Sekelas Malah Tepuk Tangan" edisi Jumat 22 Februari.

Pos-Kupang.Com. (2019) "Inilah sosok HH, Siswa SMA yang Pukul Gurunya hingga Tewas dan Kronologi Kejadian” edisi Kamis 25 Juli 2019.

Rusaln, Abi Abdillah Muhammad ibn Said (1993), `Aadab Thaalib al-'Ilm. Beirut: Daar ibn Hazm, cet. 1.

Undang-Undang Republik Indonesia Nomor 20 Tahun 2003 Tentang Sistem Pendidikan Nasional.

Zarnuji, Burhanul Islam (T.Th.). Ta'lim al-Muta'allim Thuruq al-Ta'allum. Mesir: Dar Ihya al-Kutub al-Arabiyyah, cet. 1. 